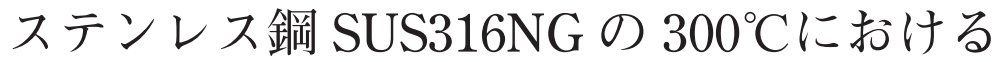 高サイクル疲労強度に及ぼす切欠き効果の特異性 ${ }^{\dagger}$
}

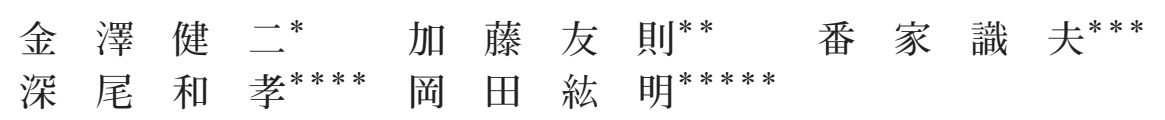

\section{Peculiarity of Notch Effect on High Cycle Fatigue Strength of a Stainless Steel SUS316NG at $300^{\circ} \mathrm{C}$}

\author{
by \\ Kenji Kanazawa ${ }^{*}$, Tomonori Kato ${ }^{* *}$, Tsuneo Banka ${ }^{* * *}$, \\ Kazutaka FuKAO ${ }^{* * * *}$ and Hiroaki OKADA ${ }^{* * * * *}$
}

\begin{abstract}
Rotating bending fatigue tests were carried out for notched specimens of a SUS316NG austenitic stainless steel at $300^{\circ} \mathrm{C}$. Nevertheless any non-propagating crack was not recognized at the root of the notch for specimens endured at $10^{8}$ stress cycles, the fatigue strength at $10^{8}$ cycles did not decrease continuously with increasing the stress concentration factor. An area of the root of notch hardened during fatigue test at $300^{\circ} \mathrm{C}$ by dynamic strain aging. The hardening behavior became remarkably with increasing the stress concentration factor. Effects of the stress concentration factor and hardening behavior on the fatigue strength cancel each other, and then dependency of the fatigue strength on the stress concentration factor becomes insensitive.
\end{abstract}

Key words : Stainless steel, High cycle fatigue strength, Elevated temperature, Notch effect, Coaxing effect, Dynamic strain aging

\section{1 緒}

言

原子力発電機器においては, 形状不連続や溶接欠陥な どの切欠きに起因する疲労き裂の発生や疲労破壞に対す る配虑が重要である。また近年, 機器の信頼性の観点か ら, 高寿命領域に扎いて, 通常の高サイクル領域とは異 なる機構による疲労現象の発生の有無について関心が高 まっている.1)

高温機器用として広く使用されるオーステナイト系ス テンレス鋼については，これまでにも高温高サイクル疲 労に関する多くのデータが蓄積されている。.2), 3) こには 切欠き材のデータもあり, 切欠き効果の温度依存性など も調べられている.3しかし, 原子力発電機器で実際に問 題となる $300^{\circ} \mathrm{C}$ とった中高温域に対して，オーステナ イト系ステンレス鋼の高寿命領域の疲労に関するデータ は必ずしも多くはない，また，それらの温度，寿命領域 に打ける疲労強度に対する切欠き効果に関するデータも 少ない。そこで, 原子力機器用熱間圧延ステンレス鋼 SUS316NG に対しては, 高寿命領域での疲労強度の切欠 き効果に関する共同研究が行われてきた。ㄱ) 5)著者らも $300^{\circ} \mathrm{C} に$ 打ける回転曲げ疲労強度に及ぼす切欠き効果を 明らかにすべく, その共同研究に参加した。
本報では, 疲労強度は応力集中係数の増加にともない 単調に低下しない，あるいは疲労強度が切欠きに対して 極めて鈍感であるという特異な結果が得られたので，そ のような結果が得られたのはなぜであろうか検討した。

\section{2 供試材および試験方法}

供試材は原子力機器用熱間圧延ステンレス鋼 SUS316NG で，溶鋼の異なる 2 ヒートを採取した，以下，ヒートの 違いをヒート A，ヒートB と区別して表す．素材はいず れも直径 $36 \mathrm{~mm}$ の丸棒で, 固溶化処理が施されている. 供試材の化学成分と機械的性質を Table 1 と Table 2 に 示す.

疲労試験片の形状を Fig. 1 に示す. 平行部直径 $8 \mathrm{~mm}$ の平滑材と, 切欠き底直径 $8 \mathrm{~mm}$ の $\mathrm{V}$ 型環状切欠き材を 用いた，切欠き底の曲率半径 $R$ を変えることにより ${ }^{6}$ 目 標の応力集中係数 $K_{t}$ を $2,3,4$ とした。平滑材の表面 の仕上げ，および切欠き材の切欠き底の仕上げは $6 \mu \mathrm{m}$ の ダイヤモンドペースト研磨によった。

疲労試験は, 電気抵抗加熱炉を有する容量 $100 \mathrm{~N} \cdot \mathrm{m}$ の クラウゼ型高速回転曲げ疲労試験機を用い, 試験温度を $300^{\circ} \mathrm{C}$, 回転速度を $100 \mathrm{~Hz}$ とした。疲労試験の打切りの 繰返し数は $10^{8}$ サイクルとした。

\footnotetext{
$\dagger$ 原稿受理 平成 19 年 4 月 16 日 Received Apr. 16, 2007 @ 2008 The Society of Materials Science, Japan

* 正 会員 中央大学理工学部精密機械工学科 ₹112-8551 東京都文京区春日, Dept. of Precision Mech., Chuo Univ., Bunkyo-ku, Tokyo, $112-8551$

**日野自動車(株)＝191-8660日野市日野台, Hino Motors, Ltd., Hinodai, Hino, 191-8660

*** 矢崎化工(株) 干359-0023 所沢市東所沢, Yazaki Industrial Chemical Corptd., Higashitkorozawa, Tokorozawa, 359-0023

****（株)シマノ＝590-8577＼cjkstart堺市堺区老松町, Shimano Inc., Sakai-ku, Sakai, 590-8577

*****十トヨタ自動車(株) 干471-8571 豊中市トヨタ町, Toyota Motor Corp., Toyota-machi, Toyota, 471-8571
} 
Table 1 Chemical composition of SUS316NG used. (mass\%)

\begin{tabular}{c|ccccccccc}
\hline Heat & $\mathrm{C}$ & $\mathrm{Si}$ & $\mathrm{Mn}$ & $\mathrm{P}$ & $\mathrm{S}$ & $\mathrm{Cr}$ & $\mathrm{Ni}$ & $\mathrm{Mo}$ & $\mathrm{N}$ \\
\hline $\mathrm{A}$ & 0.014 & 0.39 & 1.42 & 0.029 & 0.001 & 17.44 & 12.21 & 2.14 & 0.11 \\
$\mathrm{~B}$ & 0.016 & 0.37 & 1.46 & 0.030 & 0.001 & 17.31 & 11.69 & 2.12 & 0.10 \\
\hline
\end{tabular}

Table 2 Mechanical properties of SUS316NG used.

\begin{tabular}{c|c|c|c|c}
\hline Heat & $\begin{array}{c}\text { Temp. } \\
\left({ }^{\circ} \mathrm{C}\right)\end{array}$ & $\begin{array}{c}0.2 \% \text { proof } \\
\text { stress } \\
(\mathrm{MPa})\end{array}$ & $\begin{array}{c}\text { Tensile } \\
\text { strength } \\
(\mathrm{MPa})\end{array}$ & $\begin{array}{c}\text { Hardness } \\
(\mathrm{HV})\end{array}$ \\
\hline $\mathrm{A}$ & $\mathrm{RT}$ & 262 & 604 & 187 \\
$\mathrm{~B}$ & 300 & 137 & 456 & \\
\hline & $\mathrm{RT}$ & 212 & 539 & 170 \\
& 300 & 114 & 403 & \\
\hline
\end{tabular}

疲労試験中の変形挙動に関する情報を得るため，回転 曲げ疲労試験中の荷重点におけるたわみの変化を測定し た. なお，本試験に用いた㽻労試験機の構造と寸法，およ びFig. 1 に示す試験片の形状と寸法から，平滑材の場合， 試験片表面における $0.1 \%$ のひずみの変化は, 荷重点にお いては $0.63 \mathrm{~mm}$ のたわみの変化と対応することになる?7)

\section{$3 \cdot 1$ 疲労強度の $K_{t}$ 依存性}

\section{3 結果および考察}

Fig. 2 に疲労試験の結果を示す. 平滑材, 切欠き材と もに, $10^{7}$ サイクル以前に破壊しない試験片は, 試験を 中断した試験片 1 点を除き, すべて $10^{8}$ サイクルの応力 繰返しに耐え, 明瞭な疲労限が認められた。

共同研究計画の都合上, $1 S-N$ 当たりの試験片の本数 に制限があり, 10 本以下と少なかったので, 統計的処理 の下での疲労強度を求めることはできなかった。 しかし, データのばらつきは比較的小さかったので, ここでは目 視により $S-N$ 曲線を引き, $10^{8}$ サイクルの疲労強度を求 めた。 その結果を Table 3 に示す。なお，同表には後述

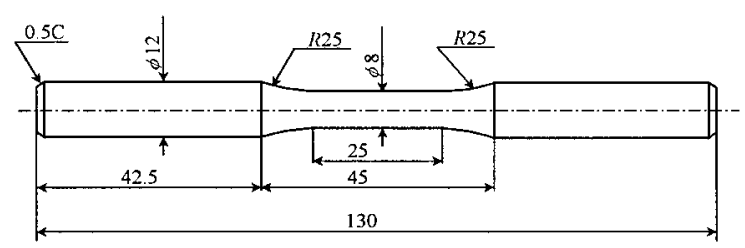

(a) Smooth specimen

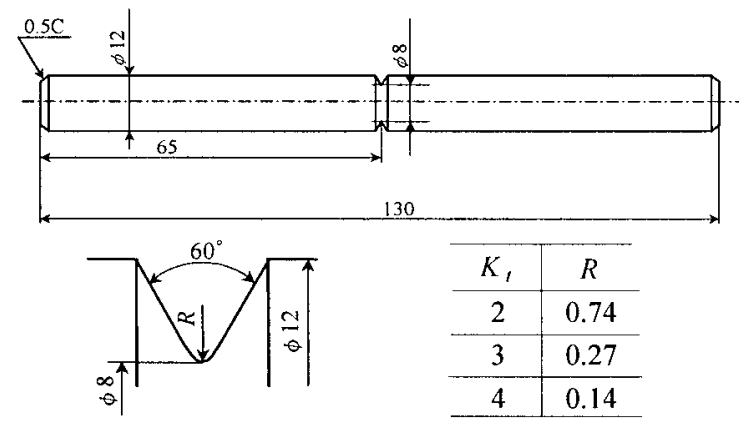

(b) Notched specimen

Fig. 1 Profile of specimens. (mm)

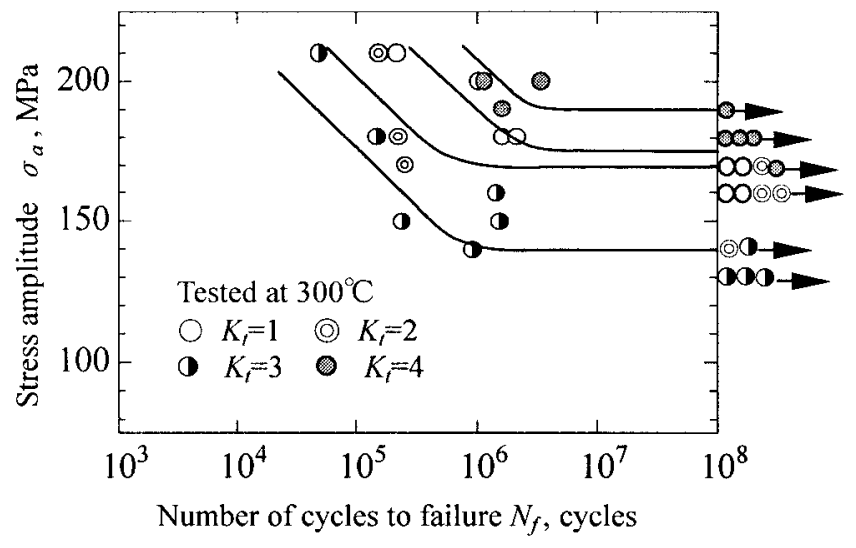

(a) Heat A

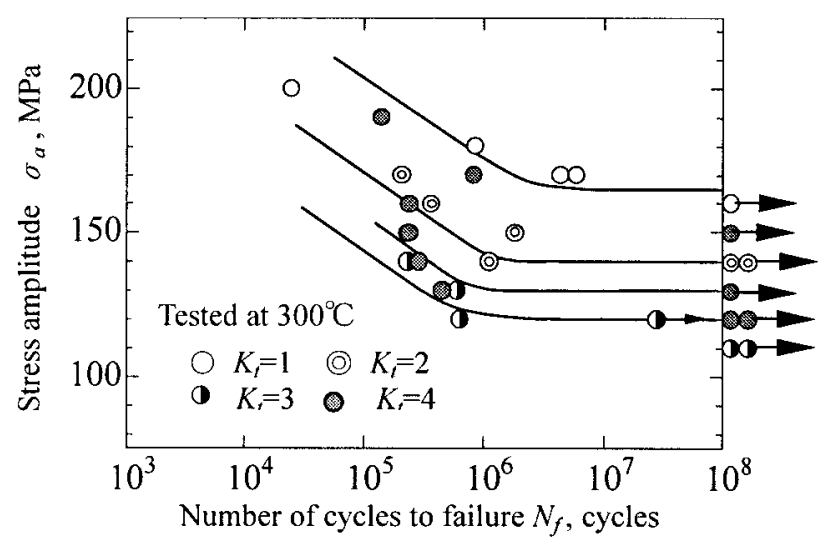

(b) Heat B

Fig. $2 S$ - $N$ curves of SUS316NG at $300^{\circ} \mathrm{C}$.

する応力漸増試験の結果も併せて示されている.

疲労強度の $K_{t}$ 依存性を Fig. 3 に示す。ここで両ヒー 卜とも平滑材打よび切欠き材の疲労強度が, $300^{\circ} \mathrm{Cにお}$ ける引張試験による $0.2 \%$ 耐力の值より大きく, $K_{t}$ の条 件によっては $0.2 \%$ 耐力の $1.3 \sim 1.4$ 倍とかなり大きな值 になっているのは興味あることである.

平滑材打よび切欠き材の疲労強度にはヒートによる相 違が認められ, 全体にヒートAの方が疲労強度は高くなっ た。オーステナイトステンレス鋼の平滑材の回転曲げ疲 労強度は, 室温の場合も含め試験温度に打ける引張強度 と良い相関があり, 引張強度の高い状況においては疲労 強度も高い值を示すことが知られている. ${ }^{3)}$ 本供試材の $300^{\circ} \mathrm{C}$ に打ける引張強度は, ヒート Aの方がヒート B に

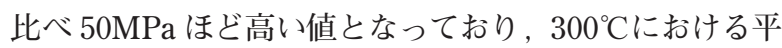
滑材の疲労強度のヒートによる差は, 材料の引張強度の 差に起因するものと考えられる，切欠き材の疲労強度の ヒートによる相違も, 基本的には素材の引張強度の差が 反映されたものと思われる. 
Table 3 Results of fatigue tests and stress increment tests at $300^{\circ} \mathrm{C}$.

\begin{tabular}{|c|c|c|c|c|c|c|}
\hline \multirow[b]{2}{*}{ Heat } & \multirow[b]{2}{*}{$K_{t}$} & \multirow{2}{*}{$\begin{array}{c}\text { Fatigue } \\
\text { strength } \\
\text { at } 10^{8} \text { cycles } \\
\sigma_{w} \\
\mathrm{MPa}\end{array}$} & \multicolumn{4}{|c|}{ Stress increment tests } \\
\hline & & & $\begin{array}{c}\text { Initial } \\
\text { stress } \\
\text { amplitude } \\
\mathrm{MPa}\end{array}$ & $\begin{array}{c}\text { Fracture } \\
\text { stress } \\
\text { amplitude } \\
\mathrm{MPa}\end{array}$ & $\begin{array}{l}\sigma_{\text {IST }} \\
\mathrm{MPa}\end{array}$ & $\begin{array}{c}\gamma \\
\sigma_{I S T} / \sigma_{w}-1 \\
(\times 100) \%\end{array}$ \\
\hline \multirow{4}{*}{$A$} & 1 & 175 & 160 & 225 & 220 & 26 \\
\hline & 2 & 170 & 160 & 245 & 240 & 41 \\
\hline & 3 & 140 & 130 & 220 & 215 & 54 \\
\hline & 4 & 190 & 180 & 205 & 200 & 5 \\
\hline \multirow{4}{*}{ B } & 1 & 165 & 160 & 195 & 190 & 15 \\
\hline & 2 & 140 & 140 & 280 & 275 & 96 \\
\hline & 3 & 120 & 110 & 185 & 180 & 50 \\
\hline & 4 & 130 & 110 & 145 & 140 & 8 \\
\hline
\end{tabular}

Fig. 3 には A, B 両ヒートの平滑材の疲労強度の平均 值 $170 \mathrm{MPa}$ を $K_{t}$ で除した值が曲線で示されている。疲労 強度が切欠きに対して敏感であれば，切欠き材の疲労強 度のプロットはこの曲線に沿うものとなるが，全く異な る $K_{t}$ 依存性を示している. 特に $K_{t}=4$ の切欠き材の疲 労強度は $K_{t}=3$ に比べ高くなるという結果が得られた。

316 ステンレス鋼については室温と $400^{\circ} \mathrm{C} \sim 700^{\circ} \mathrm{C}$ に打 いて, $K_{t}=2$ と 3 の環状切欠き材を用いて疲労強度に対 する切欠き効果が調べられている.3)その条件範囲では $700^{\circ} \mathrm{C}$ に打いて, 本結果と同様に切欠きの鋭い $K_{t}=3$ の 疲労強度が $K_{t}=2$ の疲労強度より大きくなっている。こ の場合, $K_{t}=3$ の切欠き材においては, 所定の繰返し数 に耐えた試験片の切欠き底には停留き裂が認められてい る。しかし，本供試材では一例を Fig. 4 に示すが， $K_{t}=4$ の未破断試験片に扎いて停留き裂は観察されなかった。 停留き裂が観察されなかったことは，切欠き底にき裂が 発生した試験片はすべて破断に至ることを意味し， $K_{t}$ の 大きな切欠き材におけるこのような現象は, 疲労強度が 切欠きに敏感な硬さの高い鋼において見られることで， 本供試材の場合は疲労試験中に切欠き底が硬化したこと を示唆している.

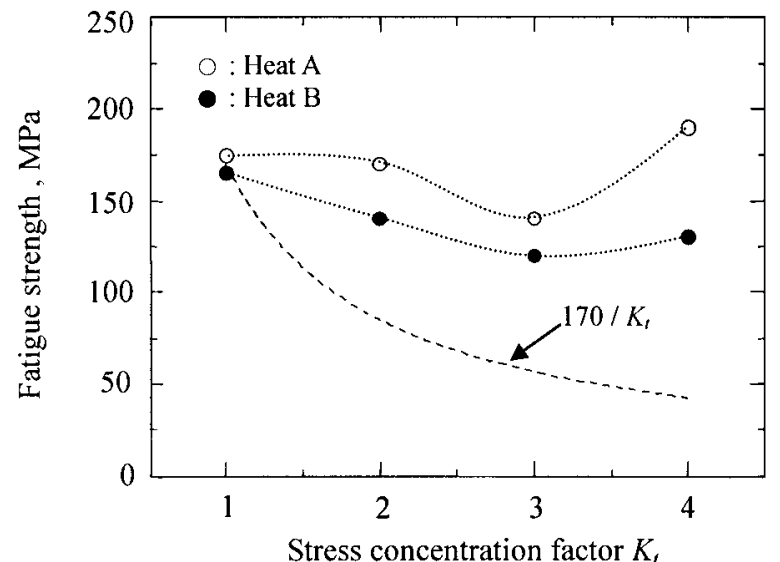

Fig. 3 Stress concentration factor dependence of fatigue strength.

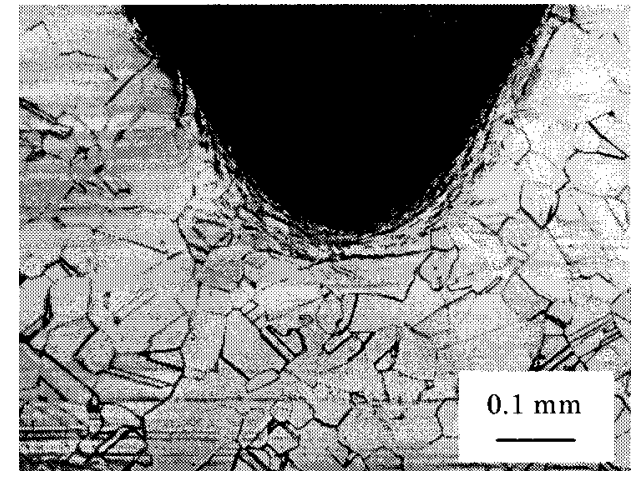

Heat A, $300^{\circ} \mathrm{C}, K_{t}=4, \sigma_{a}=180 \mathrm{MPa}, N_{f}>10^{8}$

Fig. 4 Photograph of the cross section of the fatigued specimen.

Fig. 5 に応力集中係数 $K_{t}$ と切欠き係数 $K_{f}$ の関係を示 す.いずれの $K_{t}$ に対して $K_{f}$ は 1.5 以下の值となってお り， $300^{\circ} \mathrm{C}$ に打ける疲労強度は切欠きに対して極めて針 感であるという特異な結果になっている。

\section{$3 \cdot 2$ 疲労試験中の硬化現象と応力漸増試験}

疲労強度が引張試験の $0.2 \%$ 而力比比高くなること や，瘦労強度が切欠きに対して鈍感であること，また切 欠きが鋭くても停留き裂が認められないことは，繰返し 応力のもとで材料に何らかの硬化現象が生じたことを示 している。その確認のため, 回転曲げ度労試験中の荷重 点のたわみの変化を調べた。たわみが減少することは疲 労試験中に試験片が硬化することを示す，平滑材，切欠 き材の各試験において, 疲労強度近傍の応力で破断した 試験片に対する試験中の荷重点のたわみの変化を Fig. 6 に示す.

平滑材では繰返しの初期にたわみは増加，減少する挙 動を示し，その後たわみはほぼ一定になる。破断直前で たわみは急増するが，一定の曲げモーメント下でたわみ が減少する挙動を示すことは，硬化機構の存在を裏付け るものである。このような硬化機構としては，転位と固 溶原子の相互作用による動的ひずみ時効が考えられる.

一方切欠き材では，破断直前を除き，図示されている 繰返し数 $10^{3}$ サイクル以降たわみはほぼ一定の状態を示

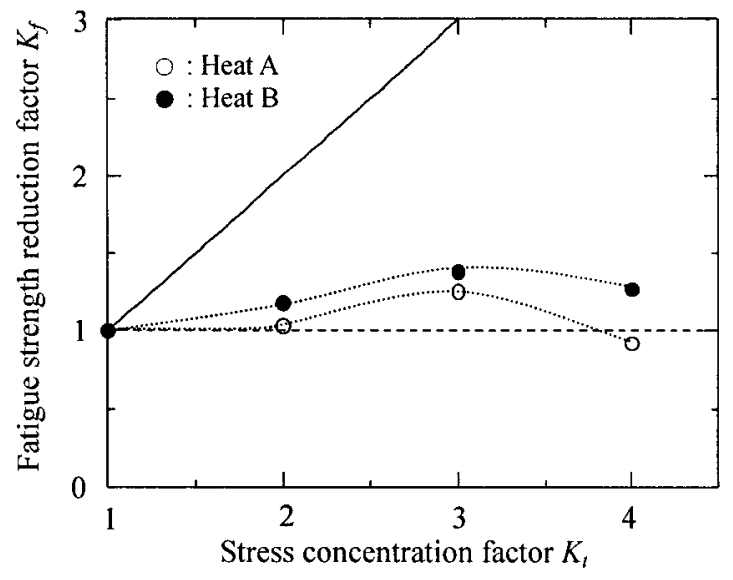

Fig. 5 Relationship between $K_{t}$ and $K_{f}$. 


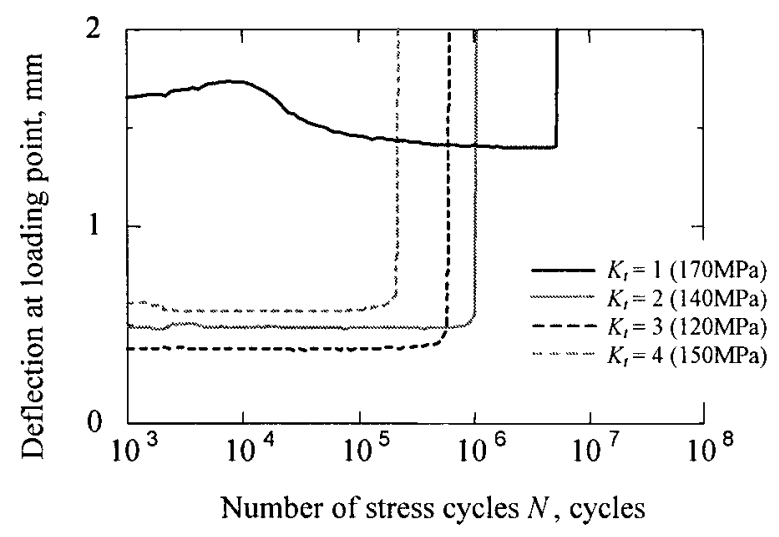

Fig. 6 Change in deflection at loading point with increasing stress cycles near fatigue strength for Heat B.

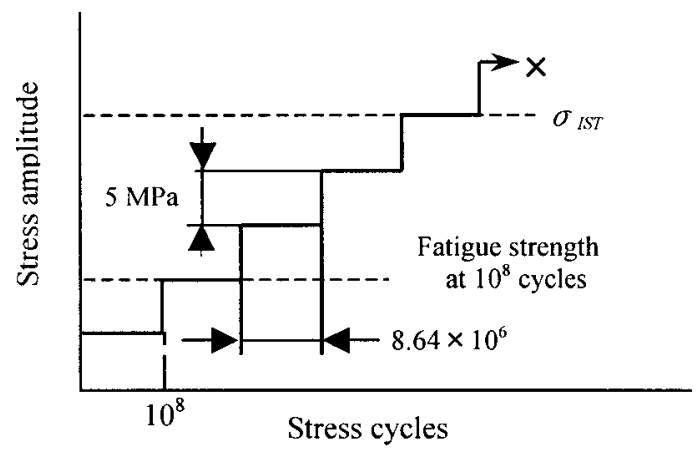

Fig. 7 Method of stress increment test and definition of $\sigma_{I S T}$.

している。これらのたわみ量は，応力振幅に比例する， それぞれの試験片形状および試験機の構造に起因する弾 性的なたわみ量とほぼ一致していた。 $10^{3}$ サイクル以降 たわみがほぼ一定状態を示す結果は, 切欠き底が応力繰 返しのごく初期の過程に抋いて硬化したことによるもの と思われる。

オーステナイトステンレス鋼では，平滑材の高温疲労 に打いて顕著なコーキシング効果が認められている.2)こ のようなコーキシング効果には，動的ひずみ時効による 硬化機構が関与していると考えられるので，切欠きに対 する動的ひずみ時効の効果を確認するために, Fig. 7 に 示すような応力漸増試験を行った。試験は，疲労強度近 傍の応力振幅のもとで $10^{8}$ サイクルに耐えた試験片に対 し， 24 時間すなわち繰返し数 $8.64 \times 10^{6}$ サイクルごとに

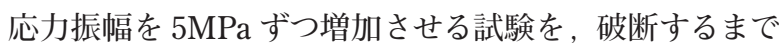
行った.

例として，ヒート B に対する応力漸増試験の試験過程 を Fig. 8 に示す. Fig. 9 には, 応力漸増試験中の各応力 ステップにおける荷重点のたわみの変化曲線を, 一例とし てヒート Bの $K_{t}=2$ の結果を示す．切欠き材は各応力ス テップにおいて, 図示されている繰返し数 $10^{3}$ サイクル以 降は, 所々に多少のたわみの増加・減少挙動が見られる が，はっきりとした大きな変化傾向は認められなかった。 また，応力漸増試験におけるこれらのたわみ量と試験応

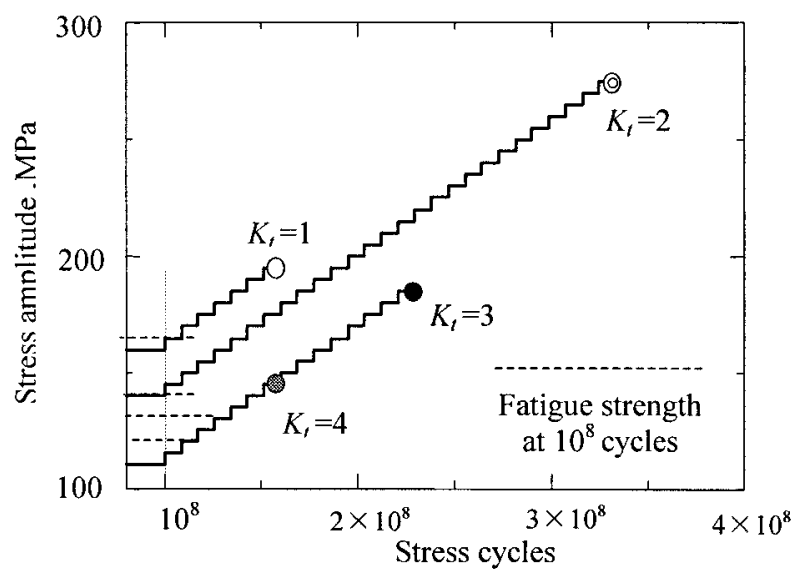

Fig. 8 Results of stress increment tests for Heat B.

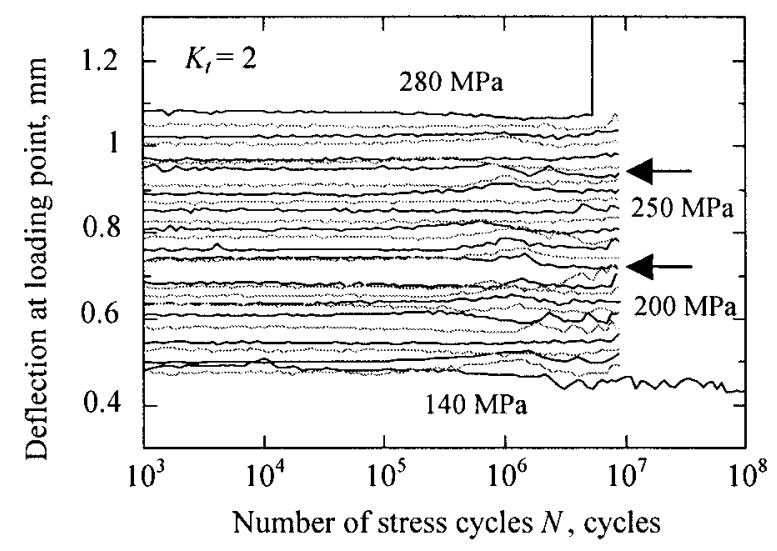

Fig. 9 Change in deflection at loading point during stress increment tests for Heat B.

力の関係についても, Fig. 10 に示すように, $K_{t}=2$ の試 験片に対する応力振幅と荷重点のたわみ量との弾性的な 関係とほぼ一致していた。

本供試材に対する通常の疲労試験では，Fig. 2 に示す ように $10^{6}$ から $10^{7}$ サイクル以前に破断しない試験片は， $10^{8}$ サイクルの繰返し数にも耐え, 明睹な疲労限が存在 する. 応力漸増試験に扎いても，破断直前の応力振幅の もとではほぼ $10^{7}$ サイクルの応力繰返しに耐えているの で，その応力振幅はその時点の状態の硬さまで硬化した 材料の切欠きの効果を含む疲労強度とみなすことができ る. 以後 Fig. 7 に示すように，応力漸増試験による破断 直前の応力振幅を $\sigma_{I S T}$ と呼ぶことにする.

なお，このような $\sigma_{I S T}$ の值は応力漸増試験における応 力階差の大きさや, 各応力における繰返し数などの試験 方法に依存するので, ${ }^{7}$ 応力漸増試験の試験方法が確立し ていない現時点では，一般的な材料特性として扱うこと はできない.しかし，同一条件のもとで実施して得られ た $\sigma_{I S T}$ の結果には, 疲労過程中の材料の硬化挙動に関す る何らかの情報が含まれることが期待される.

Table 3 に応力漸増試験における試験開始の応力振 幅，破断時の応力振幅および $\sigma_{I S T}$ の值を合わせて示す. $\sigma_{I S T}$ の疲労強度に対する増加割合を $\gamma$ として\%で表示す ることにする.

平滑試験片における $\gamma$ の值は $20 \%$ 前後になっている. 


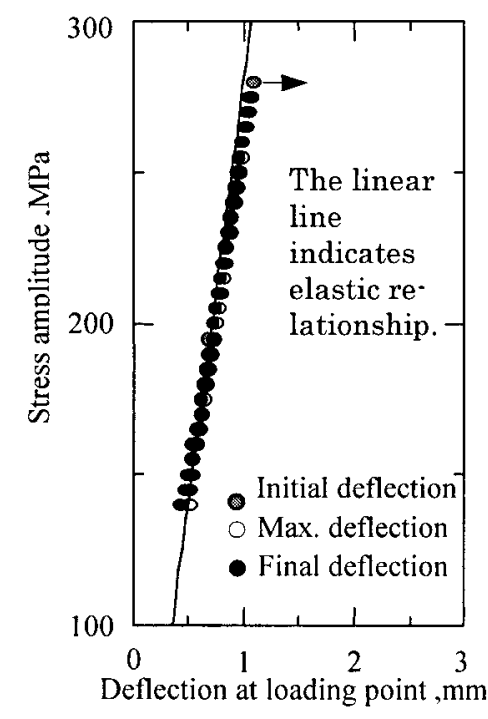

Fig. 10 Relationship between stress amplitude and deflection at loading point for notched specimen of $K_{t}=2$ at $300^{\circ} \mathrm{C}$.

SUS304 と 316 のステンレス鋼の平滑材に対しては，本 応力漸増試験とほぼ同じ試験方法のもとで, 高温疲労に おけるコーキシング効果について調べられている. ${ }^{2)} 300^{\circ} \mathrm{C}$ に打ける結果はないが, 室温に打ける $\gamma$ は $5 \%$ 以下， $400^{\circ} \mathrm{C}$ で $20 \%$ 強の值が得られている。本供試材における $300^{\circ} \mathrm{C}$ の結果はそれを補間するもので，妥当な值と思わ れる.ちなみに, 平滑材で $\gamma$ が最も大きくなるのは $600^{\circ} \mathrm{C}$ で, 30\% 前後の值になっている.2)

一方切欠き材に打ける $\gamma$ の值は， $K_{t}=2$ では $40 \sim 90 \%$ と大きく，顕著なコーキシング効果が認められたことにな る。しかし， $K_{t}$ が 3,4 と大きくなるにしたがい，コーキ シング効果は認められるものの, $\gamma$ の值は低くなる傾向 を示し,$K_{t}=4$ では $10 \%$ 以下の值となった。

ステンレス鋼の高温に打ける動的ひずみ時効による硬 化は, 繰返し塑性ひずみ振幅が大きいより跾しい応力・ ひずみ状況下で顕著に起こるといわれている. ${ }^{8)}$ 平滑材に比 ベ切欠き材に扑てコーキシング効果が顕著に認められる のは, 切欠き底に打ける応力・ひずみ履歴が厳しく, 動 的ひずみ時効が顕著に現れたことによるものと思われる。

それでは, コーキシング効果の指標である $\gamma$ の值が $K_{t}=$ 2 で最も大きく,$K_{t}$ が 3,4 と切欠き底の応力・ひずみ履 歴がより䩦しくなると低下するのはなぜであろうか. こ の点については, 応力漸増試験に打ける疲労強度近くの 最初の応力振幅が繰返される段階において, $K_{t}$ の大きな 試験片ほど, 動的ひずみ時効による硬化が十分に起こる ため, 応力漸増過程での動的ひずみ時効による硬化に対 する余裕が少なくなったと考えると理解できる.

\section{$3 \cdot 3$ 硬化現象確認のための硬さ測定}

疲労試験中に生じた硬化の程度を確認するために, 平 滑材, 切欠き材に対する通常の疲労試験後の硬さを調べ た. 試料は破断面から約 $10 \mathrm{~mm}$ で切断し, 破断面が表面 に出るよう樹脂に埋め込み, 破断面の凹凸がなくなるま でエメリー紙およびバフにより研磨した。測定にはビッ
カース硬さ試験機を使用した，測定箇所は，平滑材では 平行部表面近傍, 切欠き材では切欠き底近傍として，いず れも表面から $0.05 \mathrm{~mm}$ の深さの位置で, 円周方向に沿っ て等間隔に $120 〜 240$ 点測定した.

ヒート B の平滑材と切欠き材の硬さの分布を Fig. 11 に示す。供試材の硬さは $170 \mathrm{HV}$ であるので, 各試験片 とも $300^{\circ} \mathrm{C} に お け る$ 疲労試験により硬さは高くなってい ることがわかる．分布全体および分布のピークに対応す る硬さは，切欠きが鋭くなると高硬さ側に移っている. 通常の疲労試験に打いても $K_{t}$ の大きな試験片ほど，前節 で述べた動的ひずみ時効による硬化が十分に起こること を裏付けている.

このように繰返し応力下で硬化現象が現れ，またその 程度が鋭い切欠きほど顕著であることは，本供試材の $300^{\circ} \mathrm{C}$ における疲労強度は切欠きに対して鈍感であると いう結果を，定性的にではあるが説明付けるものと思わ れる.すなわち，一般的には切欠き材の疲労強度は切欠 きが鋭いほど低下するが，本供試材の場合， $300^{\circ} \mathrm{C} て ゙ は ，$ 切欠きが鋭いほど切欠き底が疲労試験中に動的ひずみ時 効により硬化されるので, 切欠きが鋭いほど疲労強度は 低下するという現象が相殺される結果になったものと考 えられる。

応力漸増試験の過程でも硬化することが予想されるの で，応力漸増試験で破断した試験片の硬さを同様に調べ た。その結果を Fig. 12 に示す。平滑材の硬さ分布は Fig. 11 に示す硬さ分布と比べ, 若干高硬さ側にシフト しているものの大きな相違は認められない.一方, 切欠 き材の硬さ分布においては $K_{t}$ による相違はほとんどなく なり, またピークの位置は Fig. 11 に示す $K_{t}=4$ の切欠 き材の硬さ分布のピークよりもやや高硬さ側にシフトし ている. Fig. 11 の結果と比べると, 切欠き材では $K_{t}$ が 大きくなるほど, 応力漸増過程での硬化の増加幅はわず かになることが明らかとなり，この点に打いても前節で 述べた， $K_{t}$ の大きな試験片ほど応力漸増過程での動的ひ ずみ時効による硬化に対する余裕が少なくなると考えた ことが裏付けられた。

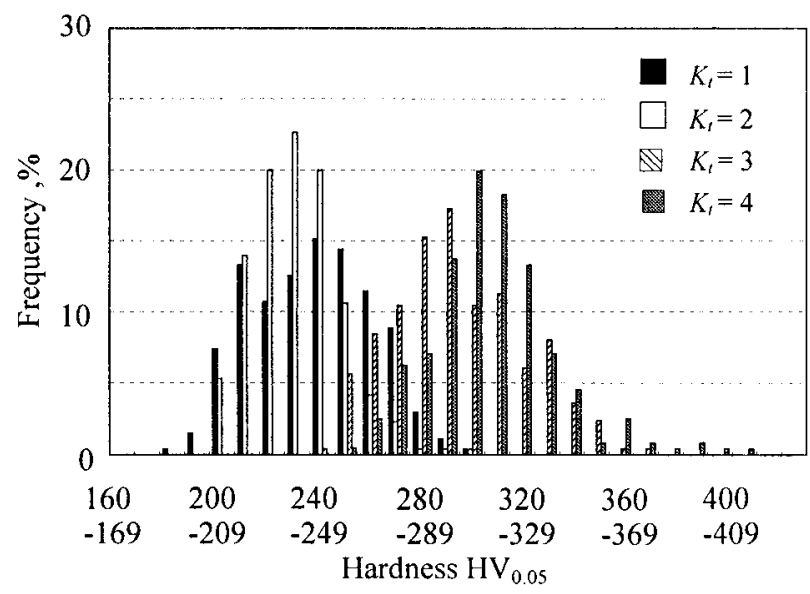

Fig. 11 Room temperature hardness of fatigued specimens of Heat B by conventional fatigue tests at $300^{\circ} \mathrm{C}$. 


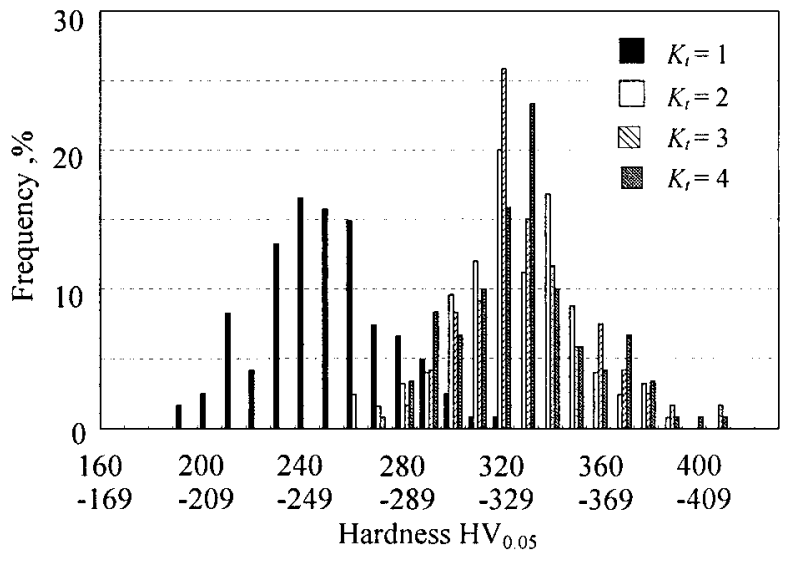

Fig. 12 Room temperature hardness of fatigued specimens of Heat B by stress increment fatigue tests at $300^{\circ} \mathrm{C}$.

切欠き材の応力漸増試験に沏いて, 破断時点の切欠き 底の硬さは $K_{t}$ によらずほぼ一定の值になっていた。この ことは, 応力振幅を漸増していくことにより動的ひずみ 時効によって硬化は進むが， $K_{t}$ によらず硬化の限界はほ ぼ一定で，その状態で試験片は破断したことを示してい る。そのときの硬さ分布のピークに対応する硬さは，室 温において $330 \mathrm{HV}$ となった。

\section{$3 \cdot 4$ 硬化状態の疲労強度と $\boldsymbol{K}_{\boldsymbol{t}}$ 依存性}

Fig. 13 は, 応力漸増試験による $\sigma_{I S T}$ を応力集中係数 $K_{t}$ に対してプロットしたものである。困には，A，B両 ヒートの $10^{8}$ サイクル疲労強度の平均值と, 平滑材の疲 労強度を $\alpha$ とし， $\alpha$ を $200,300,400,500,600 \mathrm{MPa}$ と した場合の $\sigma_{w}=\alpha / K_{t}$ の曲線群を合わせて示している.

切欠き材の $\sigma_{I S T}$ の結果をみると, $\sigma_{I S T}$ は $K_{t}$ の増加に 伴い減少している。 $\sigma_{I S T}$ は応力漸増試験により硬化した 状態での疲労強度とみなしたが，切欠き材に打ける破断 時の硬化した状態における硬さは $K_{t}$ によらずほぼ同じに

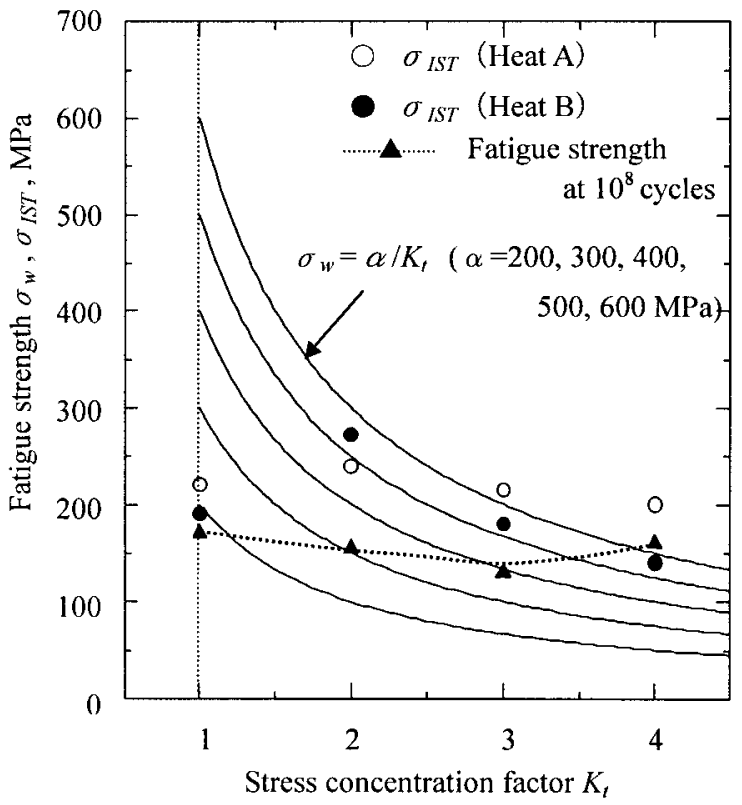

Fig. 13 Results of stress increment fatigue tests.
なっていた。したがって切欠き材に対する $\sigma_{I S T}$ の $K_{t}$ 依 存性は，そのような硬さ状態の材料に対する疲労強度の $K_{t}$ 依存性を表しているものと思われる.

それではそのような硬さ状態，すなわち室温における 硬さが $330 \mathrm{HV}$ であるような状態における，平滑材の $300^{\circ} \mathrm{C}$ における疲労強度はどの程度になるのであろうか. 室温においては，固溶化処理されたオーステナイトステ ンレス鋼を含め, 焼ならし状態の炭素鋼，調質処理され た炭素鋼，低合金鋼などを一括して，素材のビッカース 硬さと平滑材の回転曲げ疲労強度とは良い相関関係にあ ることが知られている.9) その関係からすると，切欠き材 の硬さ分布のピークに対応する硬さ $330 \mathrm{HV}$ に対する室温 における平滑材の回転曲げ疲労強度は, 500 〜 $600 \mathrm{MPa}$ と推定される。

切欠き材に対する $\sigma_{I S T}$ の $K_{t}$ 依存性のプロットは $\alpha$ を 500，600MPa とした $\sigma_{w}=\alpha / K_{t}$ の曲線群の中間に位置 している.硬化した状態における平滑材の $300^{\circ} \mathrm{C}$ の疲労 強度を 500 〜 600MPa とするならば，硬化した状態の疲 労強度は切欠きに対して極めて敏感になるといえる。こ れは，強度の高い鋼の疲労強度は切欠きに対して敏感で， $K_{f}$ の值は $K_{t}$ に近くなると一般にいわれていることと一致 する。しかし，室温における硬さから推定される痛労強 度の值を $300^{\circ} \mathrm{C} に お け る$ 疲労強度に適用することには， あまりに過大に評価することになるのではないかとの懸 念がのこる.

$\alpha$ を $400,500 \mathrm{MPa}$ とした $\sigma_{w}=\alpha / K_{t}$ の曲線群と切欠き 材に対する $\sigma_{I S T}$ の $K_{t}$ 依存性のプロットとの関係は，機械 構造用鋼に見られる室温における停留き裂の存在しない 疲労強度の $K_{t}$ 依存性と類似の傾向を示している。硬化し

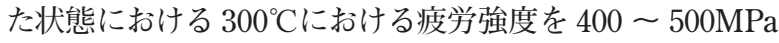
とする根拠はないが，何らかの方法で実際に確認するこ とが必要である。

なお，平滑材の応力漸増試験における $\sigma_{I S T}$ の值は，切 欠き材の $\sigma_{I S T}$ から外挿される平滑材の疲労強度には遠く 及ばなかった。 また，平滑材に打ける応力漸増試験後の 表面近傍の硬さは，切欠き材ほど大きはなっていなかっ た。これは，平滑材の表面部では，応力・ひずみ履歴が 穏やかなため動的ひずみ時効による効果が進まず，十分 に硬化する前に, 繰返し応力のもとでの疲労破壊が進行 したことによるものと考えられる。

同様なことは通常の疲労試験の過程でも起こるものと 思われる。すなわち，鋭い切欠き底ほど動的ひずみ時効 による硬化がより顕著に進むので，それぞれの切欠き底 の硬さに対応する平滑材の疲労強度は $K_{t}$ が大きくなるほ ど高くなる。したがって通常の疲労試験によって得られ る疲労強度の $K_{t}$ 依存性といっても, Fig. 13 に示すよう に $K_{t}$ が大きくなるほど， $\alpha$ がより大きな $\alpha / K_{t}$ の曲線に 対応した疲労強度になると考えられる。

このように考えると，本供試材の $300^{\circ} \mathrm{C} に お け る$ 疲労 強度の切欠き効果の特異性は, 疲労過程中の動的ひずみ 時効の程度と疲労破壊の進行との兼ね合いでもたらされ たものと理解することができる。 
4 結

\section{言}

原子力機器用熱間圧延ステンレス鋼 SUS316NG の $300^{\circ} \mathrm{C}$ における疲労強度に及ぼす切欠き効果を明らかに すべく，平滑材打よび応力集中係数 $K_{t}$ が $2,3,4$ の環状 切欠き材に対して回転曲げ疲労試験を行い以下の結果を 得た。

(1) いずれの切欠き材において，切欠き係数は 1.5 よ り小さな值になっており, 疲労強度は切欠きに対して極 めて鈍感であった。

(2) 試験片は疲労試験中に動的ひずみ時効により硬化 し，硬化の程度は切欠きが鋭いほど大きくなった。

(3) 切欠き材に打けるコーキシング効果は， $K_{t}$ が小さ いほど顕著に認められたが，破断時の切欠き底の硬さ分 布は $K_{t}$ によらずほぼ一定となった。

（4）応力漸増試験により得られる硬化した状態での疲 労強度は切欠きに対して敏感で，一般的な鋼の切欠き効 果と同等なものとみなせた。

（5）疲労強度が切欠きに対して鈍感である理由は，切 欠きが鋭いほど疲労過程中に切欠き底の硬化が顕著に起 こるため, 切欠きによる疲労強度の低下が相殺される結 果と考えられた。

本研究は東京電力(株)の委託による (社) 日本溶接協会原 子力研究委員会 GCF 小委員会, 同 GCF2 小委員会（主 查：小林英男 東京工業大学教授）で, 著者等の分担し たラウンドロビン試験の成果の一部である．東京電力(株) をはじめ関係各位に謝意を表す。

\section{参 考 文 献}

1) Y. Ochi and T. Sakai, "Fundamentals and recent topics on fatigue, III : Fatigue of metallic materials in the very high cycle fatigue”, Journal of the Society of Material Science, Japan, Vol.52, No.4, pp.433-439 (2003).

2 ) K. Kanazawa and S. Yoshida, "High-temperature, rotating bending fatigue behavior of austenitic stainless steels SUS
304B and 316B", Journal of the Society of Material Science, Japan, Vol.22, No.235, pp.257-264 (1973).

3 ) K. Kanazawa, K. Yamaguchi and M. Sato, "NRIM Fatigue strength data sheet technical document, No.6, Elevatedtemperature, high-cycle fatigue properties of engineering materials for high temperature components", (1990) National Research Institute for Metals, Japan.

4) The GCF Subcommittee Organized under the Atomic Energy Research Committee in the Japan Welding Engineering Society, "Research on high cycle fatigue strength of nuclear component material" (2003) The Japan Welding Engineering Society.

5) The GCF2 Subcommittee Organized under the Atomic Energy Research Committee in the Japan Welding Engineering Society, "Research on high cycle fatigue strength of power plant component material” (2006) The Japan Welding Engineering Society.

$6)$ R. E. Peterson, "Stress Concentration Design Factors", pp.48-49 (1953) Johan Wiley \& Sons, Inc..

7 ) K. Kanazawa, K. Yamaguchi and S. Yoshida, "Coaxing effect in high-temperature fatigue of type 316 austenitic stainless steel”, Proc. 1974 Symposium on Mechanical Behavior of Materials, Vol.I, pp.525-535 (1974) The Society of Material Science, Japan.

$8)$ K. Kanazawa, K. Yamaguchi and S. Nishijima, "Mapping of low cycle fatigue mechanisms at elevated temperatures for an austenitic stainless steel”, ASTM STP 942, pp.519-530 (1988) American Society for Testing and Materials.

9) S. Nishijima, A. Ishii, K. Kanazawa, S. Matsuoka and C. Masuda, "NRIM Fatigue strength data sheet technical document, No.5, Fundamental fatigue properties of JIS steels for machine structural use" (1989) National Research Institute for Metals, Japan. 